\title{
REVIEW
}

\section{$\beta$-blockers in critically ill patients: from physiology to clinical evidence}

\author{
Silvia Coppola, Sara Froio and Davide Chiumello*
}

\begin{abstract}
This article is one of ten reviews selected from the Annual Update in Intensive Care and Emergency Medicine 2015 and co-published as a series in Critical Care. Other articles in the series can be found online at http://ccforum.com/series/annualupdate2015. Further information about the Annual Update in Intensive Care and Emergency Medicine is available from http://www.springer.com/series/8901.
\end{abstract}

\section{Introduction}

$\beta$-blockers are commonly used in the treatment of cardiovascular diseases and to reduce the risk of re-infarction and the related mortality after myocardial infarction [1]. In fact, they almost universally reduce myocardial oxygen consumption and hence the degree of cardiac ischemia. Two randomized controlled trials (RCT) demonstrated that the perioperative use of $\beta$ blockers could reduce the incidence of cardiac complications responsible for significant morbidity and mortality after cardiac surgery $[2,3]$. However, these results were not confirmed in three subsequent RCTs and in a large cohort study [4-7]. Similarly, the Perioperative Ischemic Evaluation Study (POISE) found that individuals receiving metoprolol succinate 30 days before surgery had a reduced risk of postoperative myocardial infarction compared to the control group but an increased risk of stroke and death associated with an increased incidence of hypotension, bradycardia and bleeding [8]. Over the years, these surprising results led to different changes in practice guidelines; specifically, the recent 2014 American College of Cardiology/American Heart Association (ACC/AHA) guidelines recommend that perioperative $\beta$-blockers should be started only in patients considered

\footnotetext{
* Correspondence: chiumello@libero.it

Milan University, Dipartimento di Anestesia, Rianimazione (Intensiva e

Subintensiva) e Terapia del Dolore Fondazione IRCCS Ca' Granda - Ospedale Maggiore Policlinico, Milan, Italy
}

to be at intermediate or high risk for myocardial ischemia [9].

The physiopathological concept that $\beta$-blockers can decrease tissue oxygen consumption has led several authors to investigate the role of $\beta$-blockers in critical illness, which is characterized by increased resting energy expenditure due to sympathetic activation and a hypermetabolic state. Critically ill patients admitted to an intensive care unit (ICU) are affected by different degrees of systemic inflammatory response syndrome and cardiovascular comorbidities. In this context, Christensen et al. performed the first study to investigate the association between preadmission $\beta$-blocker use and 30-day mortality among ICU patients and found reduced mortality in $\beta$-blocker users [10]. Over the last 10 years, there has been a growing interest in this topic (Table 1). The aim of this clinical review is to review the literature regarding the use of $\beta$-blockers in critically ill patients affected by sepsis, acute respiratory failure and traumatic brain injury (TBI).

\section{Beta-blockers: basic concepts}

$\beta$-blockers act on $\beta$-adrenergic receptors interfering with the ability of catecholamines or sympathomimetics to induce $\beta$-adrenergic responses. The clinical effects of $\beta$-adrenergic agonism or antagonism depend on the subtypes of receptor and on their locations. $\beta_{1}$-adrenergic receptors are located in the heart, on cardiomyocytes, sino atrial node and atrioventricular node, in the kidney, on adipocytes and on the platelets, causing an increase in heart rate, contractility, speed of atrioventricular conduction, renin secretion, lipolysis and aggregation of platelets, respectively. They can also be found presynaptically where their activation causes an increase in norepinephrine release.

$\beta_{2}$-adrenergic receptors are located on smooth muscle fibers of bronchioles, arteries, arterioles and of visceral organs, and on liver cells. Their activation results in bronchodilation, vasodilatation, glycogenolysis in the liver and tremor in skeletal muscle [11]. 
Table 1 Clinical studies investigating the role of $\beta$-blocker exposure in critically ill patients

\begin{tabular}{|c|c|c|c|c|c|c|c|}
\hline & Author & Study design & $\mathbf{N}^{\circ}$ & $\beta$-blocker & Groups & Main Outcomes & Limitations \\
\hline \multirow[t]{3}{*}{$\mathrm{ICU}$} & \multirow[t]{3}{*}{ Christensen, 2011 [10] } & \multirow[t]{3}{*}{ Observational } & \multirow[t]{3}{*}{8087} & $\begin{array}{l}\text { Metoprolol (63.4\%), } \\
\text { others (36.5\%) }\end{array}$ & ß-blockers: 1556 & \multirow[t]{3}{*}{$\begin{array}{l}\text { 3-blocker group: lower } \\
\text { 30-day mortality }\end{array}$} & $\begin{array}{l}\text { No data on in-hospital } \\
\beta \text {-blocker use }\end{array}$ \\
\hline & & & & \multirow[t]{2}{*}{ Preadmission oral use } & \multirow[t]{2}{*}{ No $\beta$-blockers: 6531} & & $\begin{array}{l}\text { No data on severity } \\
\text { scores }\end{array}$ \\
\hline & & & & & & & Study design \\
\hline \multirow[t]{15}{*}{ Septic Shock } & \multirow[t]{4}{*}{ Gore, 2006 [20] } & \multirow{4}{*}{$\begin{array}{l}\text { Interventional } \\
\text { clinical study }\end{array}$} & \multirow[t]{4}{*}{6} & Intravenous esmolol & \multirow{4}{*}{$\begin{array}{l}\text { Septic, mechanically } \\
\text { ventilated patients: } 6\end{array}$} & \multirow[t]{2}{*}{$\downarrow 20 \% \mathrm{HR}$} & No control group \\
\hline & & & & 3 hours of infusion & & & Small population \\
\hline & & & & \multirow{2}{*}{$\begin{array}{l}6-22 \mathrm{mg} / \mathrm{min} \text { to achieve } \\
20 \% \downarrow \mathrm{HR}\end{array}$} & & \multirow{2}{*}{\multicolumn{2}{|c|}{$\begin{array}{l}\downarrow \text { Cardiac index } \\
\mathrm{O}_{2} \text { consumption not altered }\end{array}$}} \\
\hline & & & & & & & \\
\hline & \multirow[t]{2}{*}{ Schmittinger, 2008 [22] } & \multirow[t]{2}{*}{ Retrospective } & \multirow[t]{2}{*}{40} & Enteral metoprolol & \multirow{2}{*}{$\begin{array}{l}\text { Septic shock and cardiac } \\
\text { depression in patients } \\
\text { with chronic } \beta \text {-blocker } \\
\text { therapy: } 40\end{array}$} & $\downarrow$ HR (target 65-95 bpm); $\uparrow \mathrm{SVI}$ & No control group \\
\hline & & & & $\begin{array}{l}\text { Within } 48 \text { hours after the onset } \\
\text { of shock or ICU admission }\end{array}$ & & $\begin{array}{l}\downarrow N E \text {, AVP and milrinone dosages } \\
\downarrow \text { lactate, creatinine }\end{array}$ & Study design \\
\hline & \multirow[t]{3}{*}{ Macchia, 2012 [23] } & \multirow[t]{3}{*}{ Retrospective } & \multirow[t]{3}{*}{9465} & \multirow[t]{3}{*}{ Preadmission oral use } & $\beta$-blockers: 1061 & \multirow{3}{*}{$\begin{array}{l}\beta \text {-blocker group: lower 28-day } \\
\text { mortality }\end{array}$} & Study design \\
\hline & & & & & \multirow[t]{2}{*}{ No $\beta$-blockers: 8404} & & $\begin{array}{l}\text { No data on severity } \\
\text { scores }\end{array}$ \\
\hline & & & & & & & $\begin{array}{l}\text { Lack of information } \\
\text { on } \beta \text {-blockers }\end{array}$ \\
\hline & \multirow[t]{6}{*}{ Morelli, 2013 [13] } & \multirow[t]{6}{*}{ RCT } & \multirow[t]{6}{*}{154} & Intravenous esmolol & $\beta$-blocker: 77 & $\beta$-blocker group: & Single center \\
\hline & & & & \multirow{3}{*}{$\begin{array}{l}\text { ICU treated to maintain } \\
\text { HR 80-94 bpm }\end{array}$} & \multirow[t]{5}{*}{ Usual care: 77} & $\downarrow$ HR (80-94 bpm) & \multirow{5}{*}{$\begin{array}{l}\text { Arbitrary selection of } \\
\text { HR threshold }\end{array}$} \\
\hline & & & & & & $\uparrow S V I$ & \\
\hline & & & & & & $\downarrow N E$ & \\
\hline & & & & $25-2000 \mathrm{mg} / \mathrm{h}$ & & $\downarrow$ fluids & \\
\hline & & & & & & $\downarrow$ 28-day mortality & \\
\hline Acute Respiratory Failure & Noveanu, 2010 [29] & Retrospective & 314 & Preadmission oral use & In-hospital & More $\beta$-blocker use in survivors & Study design \\
\hline & & & & Metoprolol (36\%), carvedilol & & $\uparrow$ mortality if discontinuation & Post-hoc analyses \\
\hline & & & & $\begin{array}{l}\text { (18\%), bisoprolol (16\%), } \\
\text { nebivolo (22\%), atenolol (4\%), } \\
\text { sotalol (3\%), celiproplol (2\%) }\end{array}$ & In-hospital survivors: 263 & of $\beta$-blockers & \\
\hline & Kargin, 2014 [35] & Retrospective & 188 & Intravenous bolus metoprolol + & $\beta$-blockers: 74 & Similar mortality & Study design \\
\hline & & & & $\begin{array}{l}\text { enteral maintenance; enteral } \\
\text { bisoprolol or carvedilol }\end{array}$ & Other HRLD: 114 & & No data on spirometry \\
\hline & & & & ICU treatment & & & \\
\hline Trauma & Arbabi, 2007 [47] & Retrospective & 4117 & In hospital treatment & $\beta$-blocker: 303 & Similar mortality rate & Study design \\
\hline & & & & & No $\beta$-blocker: 3814 & & No data on HR \\
\hline & & & & & & & $\begin{array}{l}\text { No data on severity } \\
\text { scores }\end{array}$ \\
\hline
\end{tabular}


Table 1 Clinical studies investigating the role of $\boldsymbol{\beta}$-blocker exposure in critically ill patients (Continued)

Lack of information

on $\beta$-blockers

\begin{tabular}{|c|c|c|c|c|c|c|c|}
\hline \multirow[t]{6}{*}{ TBI } & \multirow[t]{2}{*}{ Riordan, 2007 [48] } & \multirow[t]{2}{*}{ Retrospective } & \multirow[t]{2}{*}{446} & \multirow{2}{*}{$\begin{array}{l}\text { Esmolol (e.v.), propranolol } \\
\text { (e.v. or enteral), labetalol (e.v.), } \\
\text { metoprolol (e.v. or enteral) }\end{array}$} & $\beta$-blocker: 138 & \multirow{2}{*}{$\begin{array}{l}\text { Reduced mortality in } \beta \text {-block } \\
\text { group despite older and more } \\
\text { severely injured patients }\end{array}$} & Study design \\
\hline & & & & & No $\beta$-blocker: 308 & & Different $\beta$-blockers \\
\hline & \multirow[t]{2}{*}{ Inaba, 2008 [42] } & \multirow[t]{2}{*}{ Retrospective } & \multirow[t]{2}{*}{1156} & \multirow[t]{2}{*}{ In-hospital treatment } & ß-blocker: 203 & \multirow{2}{*}{$\begin{array}{l}\text { Reduced mortality in } \beta \text {-block } \\
\text { group despite older and more } \\
\text { severely injured patients }\end{array}$} & Study design \\
\hline & & & & & No $\beta$-blocker: 953 & & $\begin{array}{l}\text { Lack of information } \\
\text { on } \beta \text {-blockers }\end{array}$ \\
\hline & \multirow[t]{2}{*}{ Schroeppel, 2010 [49] } & \multirow[t]{2}{*}{ Retrospective } & \multirow[t]{2}{*}{2601} & In-hospital treatment & $\beta$-blocker: 506 & \multirow{2}{*}{$\begin{array}{l}\text { Similar mortality between groups } \\
\text { despite older and more severely } \\
\text { injured } \beta \text {-blocker patients }\end{array}$} & Study design \\
\hline & & & & $\begin{array}{l}\text { Atenolo, carvedilol, esmolol, } \\
\text { labetalol, metoprolol, nadolol, } \\
\text { propranolol, sotalol }\end{array}$ & No $\beta$-blocker: 2095 & & Different $\beta$-blockers \\
\hline
\end{tabular}

Cotton, 2007 [46]

Retrospective

$420 \beta$-blocker therapy for 2 or more consecutive days in hospital

B-blocker: 174

Metoprolol, propranolol, labetalol, atenolol, esmolol, sotalol propranolol, sotalol $\beta$-blocker: reduction in mortality Study design

despite more severe injury, older

patients, lower predicted

Lack of information

on $\beta$-blockers

Different $\beta$-blockers

No data on neurological

outcomes

Selection of clinical studies from the last 10 years. Studies are grouped according to specific categories of critical illness: General admission to ICU, septic shock, acute respiratory failure, trauma and traumatic brain injury.

ICU: intensive care unit: HR: heart rate; BP: blood pressure; TBl: traumatic brain injury; HRLD: heart rate-limiting drug: SVl: stroke volume index; NE: norepinephrine; AVP: arginine-vasopressin; RCT: randomized control trial; bpm: beat per minute; e.v.: endovenous. 
$\beta$-adrenoceptor antagonists with a specific affinity for $\beta_{1}$-receptors are defined as cardioselective (atenolol, bisoprolol, esmolol, metoprolol), those acting on $\beta_{1}$ - and $\beta_{2}$-receptors are defined as non-selective (propranolol, pindolol, timolol and nadolol). This receptor selectivity is dose-dependent and is lost when large doses of antagonist are administered.

The clinical effects and comparative characteristics of $\beta$-adrenergic receptor antagonists are summarized in
Figure 1. The principal properties exploited in clinical practice are negative inotropism and chronotropism to reduce heart rate, blood pressure and myocardial work. Of course, the decrease in heart rate also ensures an improvement in diastolic perfusion time and consequently in myocardial perfusion [12].

$\beta$-blocker molecules differ from each other because of their elimination half-time. The long action of some $\beta$ adrenergic blockers represents an obvious limit for their

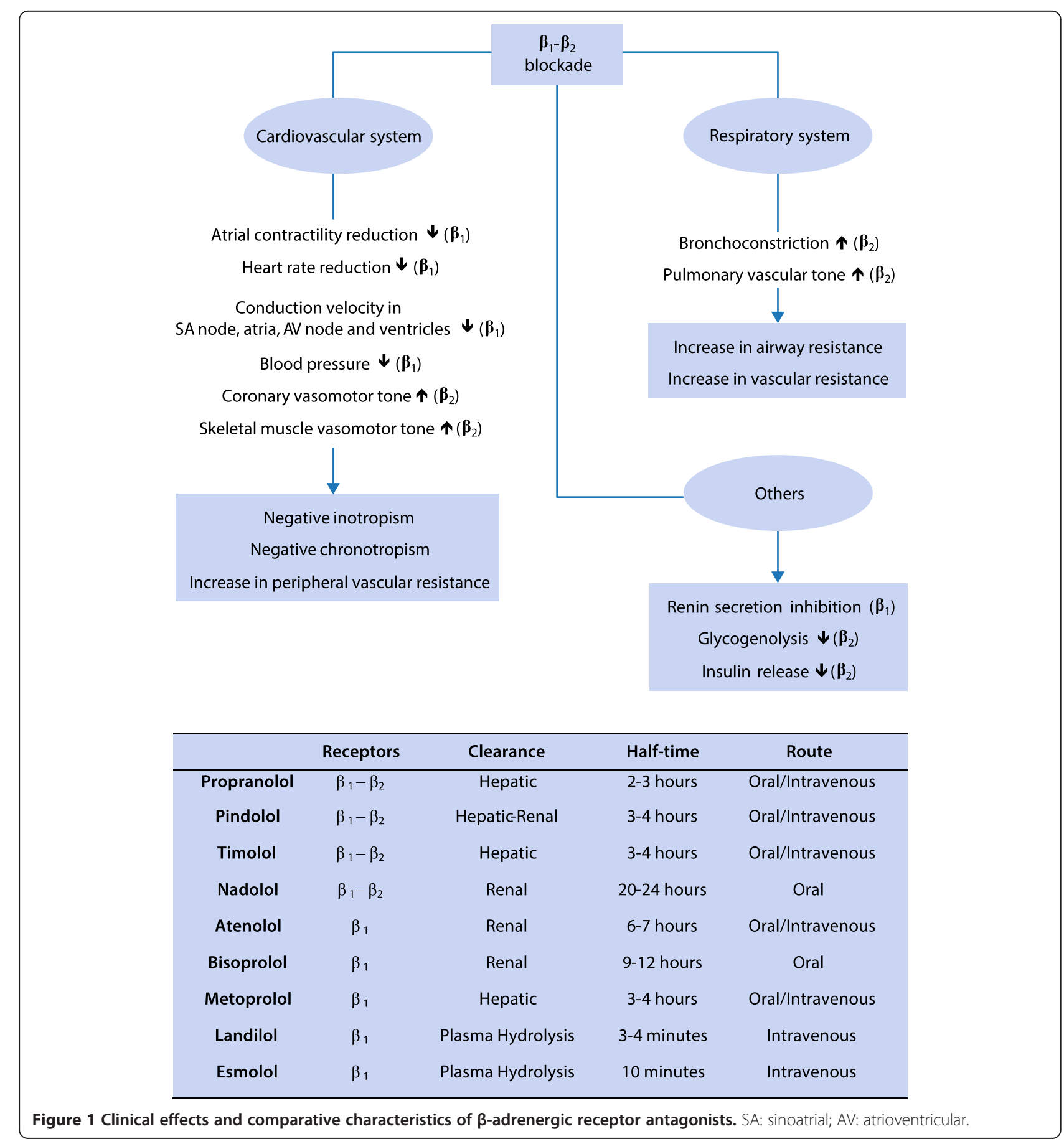


application in critically ill patients. By contrast, the pharmacological characteristics of esmolol, an ultrashort acting $\beta$-selective drug, allow titration of the dosage to specific hemodynamic endpoints, thus minimizing the incidence of adverse events, which has recently led to investigation of its application in septic shock [13].

\section{Sepsis and septic shock Physiologic rationale}

Despite recent advances in the management of septic shock [14], mortality and morbidity remain unacceptably high and sepsis treatment is an active area of research. Recent data suggest that $\beta$-blockers can provide beneficial effects in the setting of sepsis. As is well-known, sepsis is the systemic inflammatory response to infection, characterized by a multitude of pathophysiological changes in terms of cardiovascular alterations, metabolic derangements and immunomodulation. The mechanism underlying these modifications is the production of mediators, such as epinephrine, which is the adrenergic response of our organism to an external aggression. This intense adrenergic stimulation results in cardiac (increased contractility, heart rate and myocardial energy demand) and extra cardiac (catabolic state, hyperglycemia, hypercoagulability, release modulation of systemic inflammatory cytokines) effects $[15,16]$.

Although these physiological responses allow the human body to react against injury, the sympathetic activation can become deleterious when excessive and its clinical effects persist. In fact, when sepsis progresses or tachycardia persists after fluid resuscitation and pain/ agitation control, cardiac energy demand can overcome supply with the risk of cardiac dysfunction and multiorgan failure [17].

The heart is the main victim of the adrenergic stimulation because adrenergic stress is mainly mediated by $\beta$ receptors and $80 \%$ of myocardial adrenergic receptors are $\beta_{1}$ subtype [13]. In early sepsis, the adrenergic response increases cardiac contractility and heart rate to meet metabolic demands, but then cardiac depression with impaired left ventricular ejection fraction (LVEF), apical ballooning, myocardial stunning, apoptosis and necrosis occurs in up to $60 \%$ of patients with septic shock and contributes to increased mortality [18]. It has been hypothesized that the sepsis-induced cardiac depression is due to catecholamine-induced cardiomyocyte toxic effects following excessive sympathetic activation. However, it could be, at least partially, an adaptive and protective mechanism from an overwhelming stress response, whereby the heart tries to attenuate the adrenergic response by downregulation of $\beta$-adrenergic receptors and depression of post-receptor signaling.

In this context, increasing cardiac output above supernormal values by dobutamine administration showed no benefit [19], while the use of $\beta$-blockers to modulate this pathway has been suggested to have a protective role [17]. The physiologic rationale behind the clinical application of $\beta$-blockers in septic shock is not limited to the modulation of the cardiac effects of excessive sympathetic stimulation but also to the modulation of the extracardiac effects. In fact, the overwhelming adrenergic response during sepsis induces an overall catabolic state, an impairment of glucose metabolism and a derangement of the physiologic inflammatory state.

\section{Literature findings}

Preclinical studies on the use of $\beta$-blockers in different models of sepsis have provided conflicting results. Nevertheless, Berk et al. in 1970, testing the administration of propranolol infusion in 5 septic patients with refractory shock, and Gore and Wolfe in 2006 testing a 3-hour esmolol infusion in 6 normotensive septic patients, reported no detrimental cardiac effects [20,21]. Subsequently, Schmittinger et al., in a retrospective study enrolling 40 septic shock patients who were given enteral metoprolol to achieve a target heart rate of less than 95 beats $/ \mathrm{min}$, reported increased stroke volume and blood pressure with stable cardiac index and lactate, although no data on outcome were presented [22].

Recently, Macchia et al. analyzed a database of Italian ICU patients hospitalized for sepsis and found a 28-day survival advantage in patients who were taking $\beta$ blockers at the time of admission and who subsequently developed sepsis [23]. The recent study conducted by Morelli et al. is the first RCT on this topic [13]. These authors reported that a continuous esmolol infusion titrated to maintain heart rate between 80 and 94 beats/ min in septic shock patients with a heart rate of $95 / \mathrm{min}$ or higher and requiring norepinephrine to maintain mean arterial pressure (MAP) of $65 \mathrm{mmHg}$, initiated 24 hours after hemodynamic optimization, was associated with a significant reduction in norepinephrine and fluid requirements and with a decrease in 28-day mortality compared to standard care. Although Morelli et al. recognize that the right timeframe for intervention and the optimal heart rate threshold should be individualized according to a patient's hemodynamic status and preexisting comorbidities, their findings suggest that lowering heart rate improves cardiac efficiency without any detrimental effects in tissue perfusion [13]. However, some concern has been expressed regarding the interpretation of these results. In fact, the $80 \%$ mortality rate in the control group is unusually high compared to mortality rates reported in similar populations [24]; patients received large amounts of fluids during the first 96 hours although this strategy is recommended for the first 6 hours of resuscitation [14]; and the baseline 
cardiovascular parameters were slightly worst in the control group [24].

Moreover, as Morelli et al. hypothesized, the noncardiac effects of esmolol in modulating the adverse effects of catecholamines on the catabolic state, glucose metabolism, the coagulation system and cytokine production could have contributed to the observed improvement in mortality.

Indeed, it has been suggested that $\beta$-blockers can counteract the hypermetabolism of the hyperdynamic phase of sepsis to prevent the catabolic phase of the decompensated period of sepsis $[11,15]$. In particular, propranolol has been shown to decrease plasma glucose concentrations during stress, inhibiting the decrease in insulin-mediated glucose uptake and normalizing gluconeogenesis [25]. This mechanism does not seem to be influenced by selective $\beta_{1}$-antagonism [20], suggesting that non-selective $\beta$-blockade can be beneficial for glucose modulation in sepsis [11].

Moreover, it is well known that $\beta$-adrenergic receptors are involved in the cytokine production and the modulation of the cellular immune system [26,27]. However, results from sepsis models on the immunomodulatory role of $\beta$-blockade are conflicting and immunological effects in critically ill patients have not yet been investigated. In summary, from the literature in septic shock patients, the use of esmolol can reduce heart rate without adverse events; more research is necessary to investigate the effect of this approach on outcome and to reveal the clinical significance of extra-cardiac effects.

\section{Acute respiratory failure Physiologic rationale}

Acute respiratory failure is one of the major complications that can occur in patients already admitted in the ICU [28]. Among patients admitted to the ICU for acute respiratory failure, patients with acute exacerbation of chronic obstructive pulmonary disease (COPD) are often treated with oral $\beta$-blockers [29].

COPD patients generally have cardiovascular comorbidities, for example a history of coronary artery disease, chronic heart failure, arterial hypertension, atrial fibrillation and diabetes mellitus. In these patients with a high risk of cardiac events, chronic respiratory therapy with $\beta_{2}$-agonists seems to increase the incidence of cardiovascular morbidity [30]. However, the use of $\beta$-blockers has been demonstrated safe and beneficial for outcome in patients with COPD and co-existing coronary artery disease because the potential benefits may outweigh the risks [31,32]. Despite this evidence in COPD patients, the use of $\beta$-blockers in patients with acute respiratory failure is controversial. It has been reported that both selective and non-selective $\beta$-blockers increase airway hyper-responsiveness [33].
On this basis, there is a growing interest in the clinical role of $\beta$-adrenergic antagonism in COPD patients with acute respiratory failure. Moreover, the acute respiratory distress syndrome (ARDS), independent of etiology, is a critical illness and is, therefore, accompanied by sympathetic overstimulation resulting in a hyperdynamic circulation that also affects the pulmonary vasculature. In this clinical context, the potential role of $\beta$-antagonists represents an interesting field of research.

\section{Literature findings}

The effect of $\beta$-blockers in critically ill patients with acute respiratory failure has been investigated recently, without any definitive results. In 2010, Noveanu et al. retrospectively explored the impact of oral $\beta$-blocker therapy at ICU admission or before hospital discharge on in-hospital and 1-year mortality in unselected ICU patients with acute respiratory failure [29]. Patients taking oral $\beta$-blockers at the time of admission had lower in-hospital and 1-year mortality rates than other patients. This study showed for the first time a positive effect on outcome of oral $\beta$-blocker therapy in ICU patients affected by acute respiratory failure and that discontinuation of established therapy during hospitalization was associated with higher mortality rates independent of the cardiac or non-cardiac etiology of the respiratory failure. Nevertheless, the retrospective nature of this study limits the relevance of the observed results [34].

More recently, Kargin et al. performed a retrospective case-control study to compare the outcome of COPD patients admitted to the ICU for acute respiratory failure who received $\beta$-blockers (metoprolol, bisoprolol or carvedilol) versus non $\beta$-blocker drugs (diltiazem and/or digoxin and/or amiodarone) for heart rate control during the ICU stay [35]. Similar ICU, hospital and 30-day mortality rates and lengths of ICU stay were found between groups [35]. The rate of application of noninvasive ventilation was higher in patients treated with $\beta$-blockers, and the need for invasive mechanical ventilation was not significantly different between groups, suggesting that $\beta$-blockers did not lead to a worsening of respiratory conditions and that they can be used to limit heart rate in COPD patients with acute respiratory failure in the ICU. Unfortunately, spirometric data were not recorded [35]. However, previously, a meta-analysis had already demonstrated that selective $\beta$-adrenoceptor antagonists in COPD patients did not induce any significant changes in forced expiratory volume in 1 second $\left(\mathrm{FEV}_{1}\right)$ or in respiratory symptoms and did not significantly affect the $\mathrm{FEV}_{1}$ treatment response to $\beta_{2}$-agonists [32]. Despite the limited evidence, $\beta$-blockers thus seem safe in patients with acute respiratory failure. 
In experimental models, cardioselective $\beta_{1}$-blockers were found to be lung-protective. Hagiwara et al. tested the effect of landilol in a rat model of lipopolysaccharide (LPS)-induced sepsis. Wet-to-dry ratio, parenchymal congestion, edema, hemorrhage and inflammatory cells were significantly reduced in animals treated with the $\beta_{1}$-blocker [36]. More recently, an increase in the $\mathrm{PaO}_{2} /$ $\mathrm{FiO}_{2}$ ratio was observed 3 hours after administration of esmolol in a pig model of endotoxin shock, suggesting that the $\beta_{1}$-blocker did not have any negative effects [37]. In these preclinical settings, the administration of $\beta_{1}$-blockers seems to reduce pulmonary vascular flow and, thereby, the endothelial damage in the injured lung.

The clinical effect of $\beta_{1}$-blocker therapy in ARDS patients in terms of mitigation of pulmonary blood flow without a decrease in systemic hemodynamics should be further investigated. Because of the lack of evidence, RCTs testing $\beta$-adrenoreceptor antagonists in acute respiratory failure are needed to confirm the potential benefits of $\beta$-blocker therapy $[34,35]$.

\section{Acute brain injury \\ Physiologic rationale}

Acute brain injury, both traumatic and non-traumatic, is frequently associated with severe autonomic dysfunction. The underlying causes of death among patients with severe brain injury are the result not only of the primary head injury, but also of the development of nonneurologic organ dysfunction that appears to be due to sympathetic hyperactivity [38]. In fact, the interplay between the neuroendocrine system and the injured brain has been studied for decades.

The reduction in normal heart rate variability as well as the disruption in the autonomic control of heart rate was observed to correlate with the degree of the neurologic injury in patients with severe brain damage [39]. A catecholamine surge, as measured by plasma and urinary catecholamine levels, has been clearly demonstrated after TBI [38]. These abnormal levels correlated with the admission Glasgow Coma Scale (GCS) score, and with outcome, in particular with the GCS at 1 week, survival, length of stay and ventilator-dependent days. A similar hyperadrenergic state has been identified in patients with non-traumatic subarachnoid hemorrhage [40]. The clinical manifestations of these hyperadrenergic responses present with tachycardia, hypertension, mydriasis, diaphoresis, arrhythmias, ventricular wall abnormalities, myocardial ischemia and neurogenic pulmonary edema. Of note, the development of stress cardiomyopathy and of neurogenic pulmonary edema have been demonstrated to contribute to poor outcome independently of the severity of the initial brain injury [41].
Although the pathophysiology of stress cardiomyopathy (also called apical ballooning syndrome or Takotsubo syndrome) is still not completely understood, sympathetic overstimulation seems to have an important role in the development of the left ventricular dysfunction [34]. In this context, $\beta$-blockade exposure to modulate the effects of the catecholaminergic storm activated by acute brain injury after trauma or subarachnoid hemorrhage could be beneficial. Locally $\beta$-blockade may attenuate the vasoconstriction of parenchymal vessels and reduce the risk of secondary brain injury, improving perfusion and oxygenation [42]. Systemically, it can have a cardioprotective role in terms of rhythm disturbances, myocardial necrosis and left ventricular function.

\section{Literature findings}

Based on these physiological considerations, several authors have evaluated the potential benefit of $\beta$-blockers as a therapeutic option to attenuate the cerebral adverse effects and the systemic sequelae of the sympathetic activation after TBI. Unfortunately, although there are numerous preclinical studies on the use of $\beta$-blockers to mitigate inflammatory response and cardiac effects after acute brain insult, the results are conflicting. A relatively recent systematic review on the effects of $\beta$-blockers in controlled trials in TBI animal models suggested improved neurological outcome and lessened cerebral edema but with a poor methodological quality of the included studies [43].

Two small early RCTs found decreased intensity and duration of the hyperadrenergic state in patients with brain disease treated with propranolol but no data on mortality were provided $[44,45]$. More recently, two retrospective studies demonstrated that the use of $\beta$ blockers was associated with reduced mortality in TBI patients with $\mathrm{GCS} \leq 13$ [46,47]. In the most severe form of TBI, $\beta$-blocker exposure was associated with improved survival [48]. Similarly, Inaba et al. demonstrated that $\beta$-blocker exposure was an independent protective factor against death in 203 patients with isolated TBI compared to 903 patients who did not receive $\beta$ blockers. Moreover, a subgroup of elderly patients ( $>55$ years old) with severe head injury who received $\beta$ blockers had a mortality of $28 \%$, compared with $60 \%$ if they did not [42]. Similar findings were observed in a large retrospective study of 2601 blunt TBI patients [49].

Despite these results, the exact mechanism of the positive effects of $\beta$-blockers on the outcome of brain injured patients remains unclear. The current state of evidence suggests that the use of $\beta$-blockers in acute brain injury seems to have a valid rationale, although several unsolved problems regarding clinical application remain, such as whether to use selective or non-selective $\beta$-blockers, duration of treatment and dose. 


\section{Conclusion}

Many questions about using $\beta$-blockers in critically ill patients are unanswered:

- When should $\beta$-blocker treatment be started? During septic shock, recent clinical data suggest starting a $\beta$-blocker 24 hours after hemodynamic optimization [13]. During acute respiratory failure some clinical and experimental studies seem to suggest starting a $\beta$-blocker before signs of fulminant sepsis occur, whereas after brain injury $\beta$-blocker treatment should be started as soon as possible.

- Which $\beta$-blocker should be used? Currently, esmolol is the only $\beta$-blocker that has been tested in a randomized controlled study. There is not enough evidence to propose the use of a specific agent in each specific critical condition.

- How should the $\beta$-blocker be administered? Probably, as studies on perioperative patients have demonstrated, a fixed dose is not a good choice; physiological titration to heart rate or oxygen delivery in relation to oxygen demand seems more advisable.

- Finally, which patients may benefit from this therapy? Individualized treatment based on presence of comorbidities and the degree of sympathetic activation may provide better results in terms of outcome.

In conclusion, further clinical research is needed to find a balance between $\beta$-blockade and $\beta$-stimulation in acutely ill patients.

\begin{abstract}
Abbreviations
ACC/AHA: American College of Cardiology/American Heart Association; ARDS: Acute respiratory distress syndrome; AVP: Arginine-vasopressin; BP: Blood pressure; bpm: Beat per minute; COPD: Chronic obstructive pulmonary disease; e.v.: Endovenous; FEV ${ }_{1}$ : Forced expiratory volume in 1 second; GCS: Glasgow Coma Scale; HR: Heart rate; HRLD: Heart rate-limiting drug; ICU: Intensive care unit; LPS: Lipopolysaccharide; MAP: Mean arterial pressure; NE: Norepinephrine; POISE: Perioperative Ischemic Evaluation Study; RCT: Randomized control trial; SVI: Stroke volume index; TBI: Traumatic brain injury.
\end{abstract}

\section{Competing interests}

The authors declare that they have no competing interests.

\section{Declarations}

Publication charges for this article were funded by the corresponding author's institution.

Published online: 16 March 2015

\section{References}

1. Sanfilippo F, Santonocito C, Foex P. Use of beta-blockers in non-cardiac surgery: an open debate. Minerva Anestesiol. 2014;80:482-94.

2. Mangano DT, Layug EL, Wallace A, Tateo I. Effect of atenolol on mortality and cardiovascular morbidity after noncardiac surgery. Multicenter Study of Perioperative Ischemia Research Group. N Engl J Med. 1996;335:1713-20.
3. Poldermans D, Boersma E, Bax JJ, et al. The effect of bisoprolol on perioperative mortality and myocardial infarction in high-risk patients undergoing vascular surgery. Dutch Echocardiographic Cardiac Risk Evaluation Applying Stress Echocardiography Study Group. N Engl J Med. 1999;341:1789-94.

4. Brady AR, Gibbs JS, Greenhalgh RM, Powell JT, Sydes MR. Perioperative beta-blockade (POBBLE) for patients undergoing infrarenal vascular surgery: results of a randomized double-blind controlled trial. J Vasc Surg. 2005;41:602-9.

5. Juul AB, Wetterslev J, Gluud C, et al. Effect of perioperative beta blockade in patients with diabetes undergoing major non-cardiac surgery: randomised placebo controlled, blinded multicentre trial. BMJ. 2006;332:1482.

6. Lindenauer PK, Pekow P, Wang K, Mamidi DK, Gutierrez B, Benjamin EM. Perioperative beta-blocker therapy and mortality after major noncardiac surgery. N Engl J Med. 2005;353:349-61.

7. Yang H, Raymer K, Butler R, Parlow J, Roberts R. The effects of perioperative beta-blockade: results of the Metoprolol after Vascular Surgery (MaVS) study, a randomized controlled trial. Am Heart J. 2006;152:983-90.

8. Devereaux PJ, Yang H, Yusuf S, et al. Effects of extended-release metoprolol succinate in patients undergoing non-cardiac surgery (POISE trial): a randomised controlled trial. Lancet. 2008:371:1839-47.

9. Fleisher LA, Fleischmann KE, Auerbach AD, et al. 2014 ACC/AHA Guideline on Perioperative Cardiovascular Evaluation and Management of Patients Undergoing Noncardiac Surgery: A Report of the American College of Cardiology/American Heart Association Task Force on Practice Guidelines. J Am Coll Cardiol. 2014;64:e77-137.

10. Christensen $S$, Johansen MB, Tonnesen E, et al. Preadmission beta-blocker use and 30-day mortality among patients in intensive care: a cohort study. Crit Care. 2011;15:R87.

11. Novotny NM, Lahm T, Markel TA, et al. beta-Blockers in sepsis: reexamining the evidence. Shock. 2009;31:113-9.

12. Stoelting RK, Hilller SC. Alpha and beta-adrenergic receptor antagonists. In: Pharmacology \& Physiology in Anesthetic Practice. 4th ed. Philadelphia: Lippincott, Williams \& Wilkins; 2006. p. 321-37.

13. Morelli A, Ertmer C, Westphal M, et al. Effect of heart rate control with esmolol on hemodynamic and clinical outcomes in patients with septic shock: a randomized clinical trial. JAMA. 2013;310:1683-91.

14. Dellinger RP, Levy MM, Carlet JM, et al. Surviving Sepsis Campaign: international guidelines for management of severe sepsis and septic shock: 2008. Crit Care Med. 2008;36:296-327.

15. Ginsberg F. beta-blockers: more good news? Crit Care Med. 2012;40:2901-2.

16. Hamzaoui $\mathrm{O}$, Teboul JL. The role of beta-blockers in septic patients. Minerva Anestesiol. 2015. in press.

17. Rudiger A. Beta-block the septic heart. Crit Care Med. 2010;38:608-S612.

18. Vieillard-Baron A, Caille V, Charron C, Belliard G, Page B, Jardin F. Actual incidence of global left ventricular hypokinesia in adult septic shock. Crit Care Med. 2008;36:1701-6.

19. Gattinoni L, Brazzi L, Pelosi P, et al. A trial of goal-oriented hemodynamic therapy in critically ill patients. SvO2 Collaborative Group. N Engl J Med. 1995;333:1025-32.

20. Gore DC, Wolfe RR. Hemodynamic and metabolic effects of selective beta1 adrenergic blockade during sepsis. Surgery. 2006;139:686-94.

21. Berk JL, Hagen JF, Dunn JM. The role of beta adrenergic blockade in the treatment of septic shock. Surg Gynecol Obstet. 1970;130:1025-34.

22. Schmittinger CA, Dunser MW, Haller M, et al. Combined milrinone and enteral metoprolol therapy in patients with septic myocardial depression. Crit Care. 2008;12:R99.

23. Macchia A, Romero M, Comignani PD, et al. Previous prescription of betablockers is associated with reduced mortality among patients hospitalized in intensive care units for sepsis. Crit Care Med. 2012;40:2768-72.

24. Orbegozo CD, Njimi H, Dell'Anna AM, Taccone FS. Esmolol for septic shock: more than just heart rate control? Minerva Anestesiol. 2014;80:254-8.

25. Shaw JH, Holdaway CM, Humberstone DA. Metabolic intervention in surgical patients: the effect of alpha- or beta-blockade on glucose and protein metabolism in surgical patients receiving total parenteral nutrition. Surgery. 1998;103:520-5.

26. Dinarello CA, Abraham E. Does blocking cytokines in sepsis work? Am J Respir Crit Care Med. 2002;166:1156-7.

27. Oberbeck R, van Griensven M, Nickel E, Tschernig T, Wittwer T, Pape HC. Influence of beta-adrenoceptor antagonists on hemorrhage-induced cellular immune suppression. Shock. 2002;18:331-5. 
28. Ware LB, Matthay MA. The acute respiratory distress syndrome. N Engl J Med. 2000;342:1334-49.

29. Noveanu M, Breidthardt T, Reichlin T, et al. Effect of oral beta-blocker on short and long-term mortality in patients with acute respiratory failure: results from the BASEL-II-ICU study. Crit Care. 2010;14:R198.

30. Au DH, Curtis JR, Every NR, McDonell MB, Finn SD. Association between inhaled beta-agonists and the risk of unstable angina and myocardial infarction. Chest. 2002;121:846-51.

31. Albouaini $\mathrm{K}$, Andron M, Alahmar A, Egred M. Beta-blockers use in patients with chronic obstructive pulmonary disease and concomitant cardiovascular conditions. Int J Chron Obstruct Pulmon Dis. 2007:2:535-40.

32. Salpeter SR, Ormiston TM, Salpeter EE, Poole PJ, Cates CJ. Cardioselective beta-blockers for chronic obstructive pulmonary disease: a meta-analysis. Respir Med. 2003;97:1094-101.

33. van der Woude HJ, Zaagsma J, Postma DS, Winter TH, van Huist M, Aalbers R. Detrimental effects of beta-blockers in COPD: a concern for nonselective beta-blockers. Chest. 2005;127:818-24.

34. van der Jagt $M$, van der Miranda DR. Beta-blockers in intensive care medicine: potential benefit in acute brain injury and acute respiratory distress syndrome. Recent Pat Cardiovasc Drug Discov. 2012;7:141-51.

35. Kargin F, Takir HB, Salturk C, et al. The safety of beta-blocker use in chronic obstructive pulmonary disease patients with respiratory failure in the intensive care unit. Multidiscip Respir Med. 2014;9:8.

36. Hagiwara S, Iwasaka H, Maeda H, Noguchi T. Landiolol, an ultrashort-acting beta1-adrenoceptor antagonist, has protective effects in an LPS-induced systemic inflammation model. Shock. 2009;31:515-20.

37. Aboab J, Sebille $V$, Jourdain $M$, et al. Effects of esmolol on systemic and pulmonary hemodynamics and on oxygenation in pigs with hypodynamic endotoxin shock. Intensive Care Med. 2011;37:1344-51.

38. Woolf PD, Hamill RW, Lee LA, Cox C, McDonald JV. The predictive value of catecholamines in assessing outcome in traumatic brain injury. J Neurosurg. 1987;66:875-82.

39. Goldstein B, Toweill D, Lai S, Sonnenthal K, Kimberly B. Uncoupling of the autonomic and cardiovascular systems in acute brain injury. Am J Physiol. 1998;275:R1287-92.

40. Hortnagl H, Hammerle AF, Hackl JM, Brucke T, Rumpl E, Hortnagl H. The activity of the sympathetic nervous system following severe head injury. Intensive Care Med. 1980;6:169-70.

41. Bruder N, Rabinstein A. Cardiovascular and pulmonary complications of aneurysmal subarachnoid hemorrhage. Neurocrit Care. 2011;15:257-69.

42. Inaba K, Teixeira PG, David JS, et al. Beta-blockers in isolated blunt head injury. J Am Coll Surg. 2008;206:432-8.

43. Ker K, Perel P, Blackhall K. Beta-2 receptor antagonists for traumatic brain injury: a systematic review of controlled trials in animal models. CNS Neurosci Ther. 2009;15:52-64

44. Greendyke RM, Kanter DR, Schuster DB, Verstreate S, Wootton J. Propranolol treatment of assaultive patients with organic brain disease. A double-blind crossover, placebo-controlled study. J Nerv Ment Dis. 1986;174:290-4.

45. Feibel JH, Baldwin CA, Joynt RJ. Catecholamine-associated refractory hypertension following acute intracranial hemorrhage: control with propranolol. Ann Neurol 1981:340-343.

46. Cotton BA, Snodgrass KB, Fleming SB, et al. Beta-blocker exposure is associated with improved survival after severe traumatic brain injury. J Trauma. 2007;62:26-33.

47. Arbabi S, Campion EM, Hemmila MR, et al. Beta-blocker use is associated with improved outcomes in adult trauma patients. J Trauma. 2007;62:56-61.

48. Riordan Jr WP, Cotton BA, Norris PR, Waitman LR, Jenkins JM, Morris Jr JA. Beta-blocker exposure in patients with severe traumatic brain injury (TBI) and cardiac uncoupling. J Trauma. 2007:63:503-10.

49. Schroeppel TJ, Fischer PE, Zarzaur BL, et al. Beta-adrenergic blockade and traumatic brain injury: protective? J Trauma. 2010;69:776-82 